Gorohova S.M., Vasilev A.A. Ecological and geochemical assessment of the content of chemical elements and features of their spatial distribution in Fe nodules of soils in the Middle Cis-Urals

\title{
Ecological and geochemical assessment of the content of chemical elements and features of their spatial distribution in Fe nodules of soils in the Middle Cis-Urals
}

\author{
Gorokhova S.M., Vasiliev A.A. \\ Perm State Agro-Technological University
}

\begin{abstract}
This work is about the ecological and geochemical assessment of the elemental chemical composition of soil nodules in the taiga zone of the Middle Cis-Urals. The features of the spatial distribution of chemical elements in concretions of Umbric Albeluvisols Abruptic, Luvic Stagnosols Dystric, and Haplic Fluvisols Oxyaquic are characterized for the first time using atomic absorption spectrometry and scanning electron microscopy with energy-dispersive analysis. A concentric ring structure of nodules with alternating zones rich in Fe and Mn has been revealed. Nodules act as geochemical barriers and accumulate not only iron and manganese, but also $\mathrm{Cu}, \mathrm{Ni}, \mathrm{Co}, \mathrm{Zn}$, and $\mathrm{Pb}$.

Keywords: ALBELUVISOLS, STAGNOSOLS, FLUVISOLS, ORTSHTEIN, RORENSTEIN, GEOCHEMISTRY CONSTANTS, ATOMIC ABSORPTION SPECTROMETRY, SEM/EDS, FE AND MN DISTRIBUTION, RING MICROSTRUCTURE
\end{abstract}

\section{Introduction}

Ferromanganese nodules $(F M N)$ form in soils of humid landscapes [1-4]. The $F M N$ contain information about soil processes and geochemistry of elements [5-8].

The formation of the FMN is the main form of deposition of Fe and Mn oxides in soils. This is the most efficient and long-term process of metal binding in soils. Nodules are formed during the alternation of oxidizing and reducing phases of soil formation. Geneis of concretion reduces the availability of contaminant metals. Nodules are a geochemical barrier to many potentially toxic chemical elements. [4, 9-15].

The relevance of studying the processes of accumulation of heavy metals (HM) in the nodules is determined by the enrichment in the $H M$ of parent rocks and soils, variable 
Gorohova S.M., Vasilev A.A. Ecological and geochemical assessment of the content of chemical elements and features of their spatial distribution in Fe nodules of soils in the Middle Cis-Urals

redox conditions of soil formation on the eastern part of the Russian Plain (Middle Cis-Urals) [1, $3,16]$ and a high technogenic load on the environment of the region [17-24].

Genesis and geochemical features of nodules. The FMN are formed in soils of regions with common climate characteristics: heavy rainfall, low evaporation, long duration of soil freezing in winter and thawing of soil in spring, as well as repeated freezing $[25,26]$.

The formation of the FMN occurs due to cyclic changes in the redox state of soils [27], with the participation of the processes of podzolization and gleying [28], and the activity of ironreducing microorganisms [29]. F.R. Zaidelman et al. [30] established in a model experiment that the FMN are formed in one to two years.

Z.H. Sun et al. [31] identify three stages of the $F M N$ formation in poorly drained, low organic matter, silty loamy soils (Fragiudalfs) in the loess of southeastern Indiana (USA):

1) cementation of silicate potassium-sodium minerals with large pores occurs under the influence of mainly $\mathrm{Fe}$ oxides in the soil matrix in a wet state, and the formation of a nodule core;

2) with a strong drying of the soil, the body of the concretion is enriched in $\mathrm{Mn}$ in the form of concentric layers outside the core;

3) with moderate drying of the soil, concentric layers are enriched with $\mathrm{Fe}$ oxides. According to Z.H. Sun [31], the alternation of zones rich in Fe and Mn in a concentric structure indicates that oxidation and reduction processes often occurred during the formation of nodules.

P. Sipos et al. [32] came to the conclusion that the leading processes of the formation of the FMN in Gleyic Fluvisol are the formation of the outer shell and the impregnation of internal parts of the body of nodules with Fe oxides. The authors identified four stages of nodule formation:

1) cementation of large soil particles with Fe and Mn oxides with the formation of irregularly shaped aggregates;

2) formation of the outer band;

3) slow precipitation of iron and manganese oxides in the form of concentric bands;

4) peeling of the outer band from the inner layer [32].

The FMN accumulate amorphous Fe in soils with a contrasting stagnant-percolate water regime: dark-gray, dark-gray contact-gley and soddy-podzolic contact-gley soil on dual-layer deposits in the southern part of the East European Plain (Tambov Region). The ratio of acid- 
Gorohova S.M., Vasilev A.A. Ecological and geochemical assessment of the content of chemical elements and features of their spatial distribution in Fe nodules of soils in the Middle Cis-Urals

Электронный научно-производственный жсурнал «АгроЭкоИнфо»

soluble $\left(0.1 \mathrm{~N} \mathrm{H}_{2} \mathrm{SO}_{4}\right)$ forms of $\mathrm{Fe}$ and $\mathrm{Mn}$ in the composition of concretions increases in the series from dark-gray contact-gley soil to soddy-podzolic contact-gley soil [33].

It is known that minerals $\mathrm{Fe}$ and $\mathrm{Mn}$ in the composition of the $F M N$ are natural geochemical barriers for heavy metals [10, 34].

In Stagnic Fragic Albeluvisol in the foothills of the Carpathians (Poland), W. Szymanski and M. Skiba [35] found that the maximum content of the $F M N$ is characteristic of the eluvial horizon Eg and ranges from $7.71 \%$ to $27.41 \%$ of the mass of the entire soil in the horizon. The chemical composition of nodules from these soils was dominated by: $\mathrm{Fe}_{2} \mathrm{O}_{3}$ 22.7-41.9\%; $\mathrm{MnO} 2.7-5.4 \%$ and $\mathrm{AlO}$ 11.7-15.8\%. The concentration of other chemical elements was also higher than the surrounding soil material: $1.29 \% \mathrm{TiO} ; 0.06 \% \mathrm{CoO} ; 0.06 \% \mathrm{NiO} ; 0.66 \% \mathrm{CuO}$; $0.66 \% \mathrm{ZnO}$.

In the FMN in the brown forest soils of the Pacific coast of Russia (Primorsky Krai), the concentration of $\mathrm{Mn}$ is 10-40 times higher, $\mathrm{Co}$ is 5-30 times higher, and $\mathrm{Ni}$ is 3-17 times higher than in the soil. The content of $\mathrm{Zn}$ in nodules of brown forest soils is at the level of soil [36]. In meadow-brown and brown forest soils in the south of the Russian Far East (Primorsky Krai), the FMN intensively accumulate $\mathrm{Mn}, \mathrm{Co}, \mathrm{Pb}$, and $\mathrm{Ni}$ and, to a lesser extent $-\mathrm{Cu}, \mathrm{Cr}$, and Mo [10].

The FMN accumulate $\mathrm{Cd}, \mathrm{Pb}, \mathrm{Co}$, and $\mathrm{Mo}$ in arable deeply gleyed light gray soils in the southern part of the East European Plain (Tambov Region). The content of $\mathrm{Zn}$ and $\mathrm{Cu}$ in concretions of light gray soils is significantly lower than in concretions of soddy-podzolic soils of the taiga zone [37].

The FMN are significantly enriched in $\mathrm{Mn}, \mathrm{Pb}, \mathrm{Ni}, \mathrm{Cu}$ and $\mathrm{Zn}$ compared to the soil matrix of a typical Plinthudult in East China [38]. In the FMN formed in the Terra rossa of the YunnanGuizhou Highlands (Guizhou Province, China), the content of $\mathrm{Cd}$ exceeds the background by 268.13 times; $\mathrm{Pb}-39.46 ; \mathrm{Cr}-11.80 ; \mathrm{Zn}-8.43 ; \mathrm{Ni}-6.16 ; \mathrm{Cu}-3.65$ times [39]. In the arable Cutanic Luvisol in the southwestern part of the African continent (Namibia), the FMN accumulate: $\mathrm{Cd}$ 6.83; $\mathrm{Zn} \mathrm{137;} \mathrm{Cu}$ 45; $\mathrm{Pb} 597$ ppm, which is higher than the clarks of these elements [8].

In the alluvial meadow soils of the Bolshaya Kokshaga Natural Reserve in the east of the East European Plain (the Republic of Mari El), the FMN contain Mn 30 times higher than in the surrounding soil, $\mathrm{Ba}-11$ times, $\mathrm{P}, \mathrm{Ni}, \mathrm{Zn}, \mathrm{As}, \mathrm{Fe}$, and $\mathrm{S}$ - more than two times [40]. 
Gorohova S.M., Vasilev A.A. Ecological and geochemical assessment of the content of chemical elements and features of their spatial distribution in Fe nodules of soils in the Middle Cis-Urals

The interior of nodules is an important basis for conclusions about soil processes and the ecological state of the environment $[5,10,41-43]$. The features of the internal structure and spatial distribution of chemical elements in the $F M N$ were studied in the subtropical Typic Plinthudult formed on Quaternary red-colored rocks of East China. [38]. The studied Fe-Mn nodules are composed of quartz, muscovite, and kaolinite. The presence of quartz and kaolinite suggests authigenic formation of concretions, probably as a result of impregnation and cementation of the soil matrix with $\mathrm{Fe}$ and $\mathrm{Mn}$ oxides. The total $\mathrm{Fe}$ content decreases with increasing nodule size, while the total Mn content, on the contrary, increases. The content of mobile Fe oxides varies from 73 to $75 \%$ of the total $\mathrm{Fe}$, and mobile Mn oxides is about $96 \%$ of the total $\mathrm{Mn}$ content. It has been established that $\mathrm{Pb}$ is mainly associated with Fe oxides, while $\mathrm{Cu}, \mathrm{Ni}, \mathrm{Cd}$, and $\mathrm{Zn}$ are mainly associated with $\mathrm{Mn}$ oxides [38].

The elemental chemical composition of the FMN in soils of the Middle Cis-Urals was studied by Yu.N. Vodyanitsky, A.A. Vasiliev and etc. [1, 4, 11, 12, 44, 45]. The concentration of the $H M$ and As in the composition of the FMN in soils of the region varies in a wide range: $\mathrm{Zn}$ 59-139, As 14-75, Cr 34-246, Ni 95-492, Cu 23-134, Mn 465-41433 ppm. It depends on the genesis soils and rocks, redox regimes of soils, the degree of anthropogenic load on the soil cover of the studied landscapes $[4,41]$.

Despite extensive studies on the study of the elemental chemical composition of Fe-Mn nodules in the soil of the Middle Cis-Urals, information on the distribution of chemical elements in the internal space of these concretions is limited [4] and is often conjectural character [20, 42].

The purpose of the research is the ecological and geochemical assessment of the elemental chemical composition of the $F M N(1)$; revealing the features of the spatial distribution of chemical elements in the body of the FMN (2).

For this study we chose soils, which are characterized by alternation of restorative phases of temporary excessive moisture providing mobilization and migration of $\mathrm{Fe}$ and $\mathrm{Mn}$ ions, and subsequent phases of oxidation, when metals are deposited in pores, on the surface of primary soil minerals, as part of biogenic fragments (roots, stems plants, etc.).

\section{Materials and methods}

The objects of study were from two soils zones of the Perm region: $1^{\text {st }}$ zone - the area with the heavy loamy Umbric Albeluvisols Abruptic and Rendzic Leptosols Eutric; $2^{\text {nd }}$ zone - 
Gorohova S.M., Vasilev A.A. Ecological and geochemical assessment of the content of chemical elements and features of their spatial distribution in Fe nodules of soils in the Middle Cis-Urals

Электронный научно-производственньй жсурнал «АгроЭкоИнфо»

the area of the heavy loamy Umbric Albeluvisols Abruptic (Fig. 1) [46]. Emissions from industrial enterprises affect the survey area, which is located in the zone of influence of the Perm-Krasnokamsk agglomeration [24].

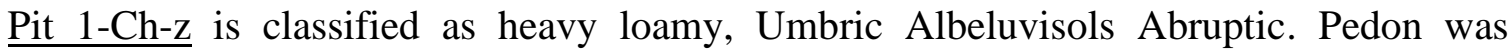
formed on eluvial-deluvial deposits. The pit was laid on a gentle slope of southeastern exposure in the vicinity of SNT Cheremshanka, Mostovaya village. Coordinates: $57^{\circ} 82^{\prime} 86^{\prime \prime} \mathrm{N}, 56^{\circ} 51^{\prime}$ $12 "$ E. The soil has been in a fallow state for more than 20 years. Humidification of soil is atmospheric, short-term excessive.

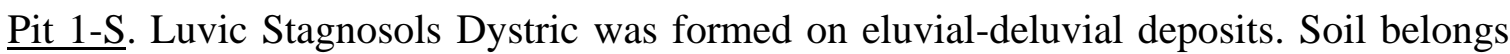
to clay varieties by granulometry. The pit was laid down in a low watershed plateau on the southern outskirts of the city of Perm. Coordinates $57^{\circ} 95^{\prime} 14^{\prime \prime} \mathrm{N}, 56^{\circ} 29^{\prime} 51^{\prime \prime}$ E. Type of land is an unused pasture. Humidification of soil is atmospheric, temporarily excessive, with periodic formation of perched water.

Pit 1-N. Haplic Fluvisols Oxyaquic is formed on recent alluvium. Soil granulometry is heavy loamy. The site for laying the pit is the central floodplain on the right bank of the Syn river in the vicinity of the village of Lugovaya, Nytvensky district. Coordinates: $58^{\circ} 26^{\prime} 64^{\prime \prime} \mathrm{N}$, $55^{\circ} 59^{\prime} 78^{\prime \prime}$ E. Type of land is a hay. Humidification of soil is atmospheric, short-term, temporarily excessive.

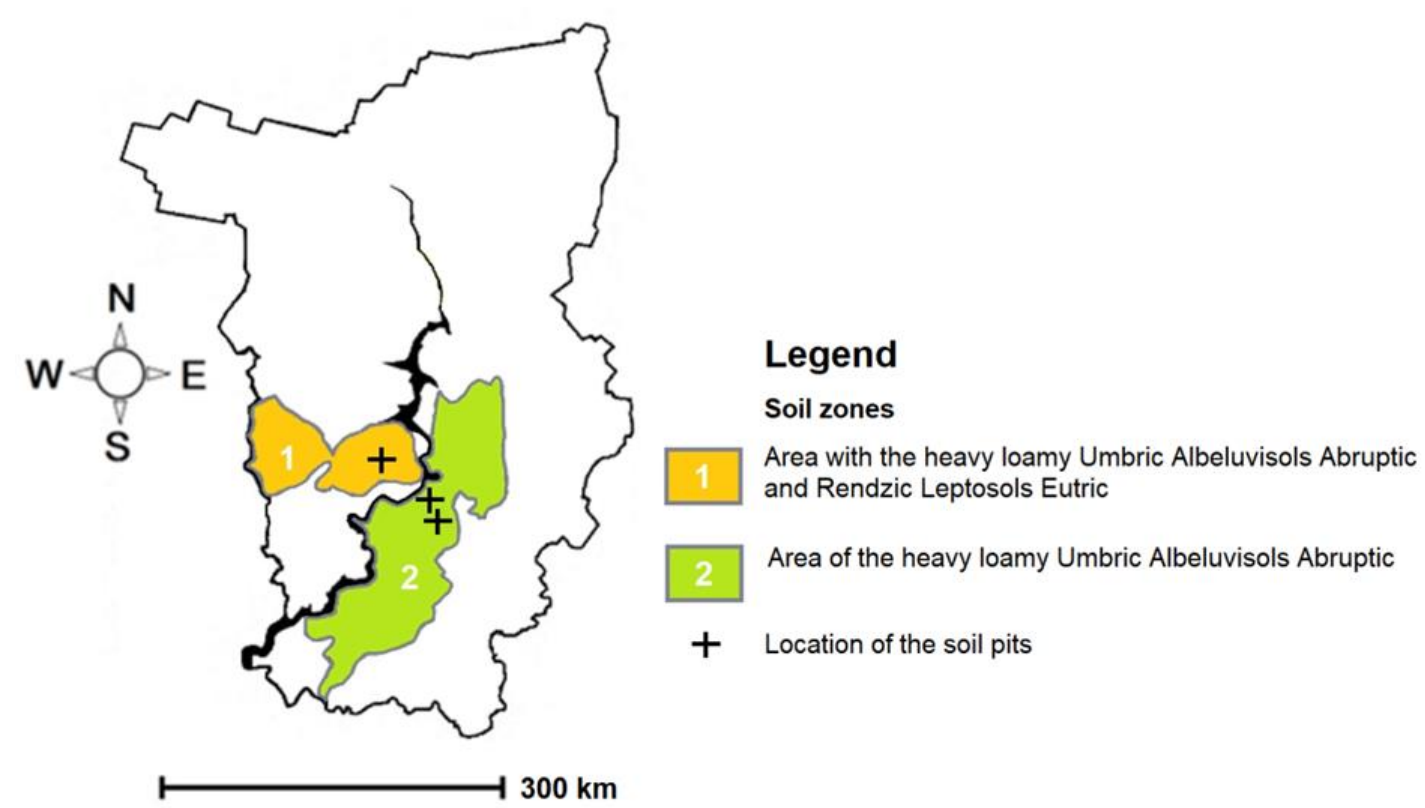

Fig. 1. Location of research objects on the map of soil regions of the Perm Krai according to N.Ya. Korotaev [46] 
Gorohova S.M., Vasilev A.A. Ecological and geochemical assessment of the content of chemical elements and features of their spatial distribution in Fe nodules of soils in the Middle Cis-Urals

\section{Research methods}

Establishment of soil sections, morphological description of the soil profile and soil sampling were carried out in accordance with the methods of large-scale soil surveys [47]. Nodules were separated from the fine soil $(\mathrm{d}>1.0 \mathrm{~mm})$ by wet sieving method.

The exchange acidity of the soil was determined by the method of TsINAO $(1 \mathrm{H} \mathrm{KCl}$ at soil $=1: 2.5$ ). The content organic carbon was determined using the Turin method. The sum of exchange bases was determined by the Kappen-Hillkowitz method. The granulometric composition of the soil was determined by the Kachinsky pyrophosphate method [47].

The total chemical composition of the soil and nodules was analyzed by atomic absorption spectrometry $(A A S)$. A sample weighing 0.2-0.4 $\mathrm{g}$ with an accuracy of $10^{-4}$ grams was decomposed with $5 \mathrm{ml}$ of a mixture of concentrated nitric and hydrochloric acids (1:3). The $A A S$ samples were carried out in triplicate on an iCE 3500 instrument with flame atomization (Thermo Scientific, USA).

To prepare nodule samples for electron microprobe analysis, they were filled with epoxy resin, polished sections with a cross section of nodules were made with a diamond saw blade, and their surface was polished. Polished surfaces were covered with carbon tape for electron microanalysis. Electron probe microanalysis of nodules was performed using an FEI Quanta 650FEG high resolution scanning electron microscope (FEI, USA) with an EDAX Octane Elite energy dispersive spectrometer. The study of polished sections was carried out in a low vacuum mode at a chamber pressure of $200 \mathrm{~Pa}$ and an accelerating voltage of $20 \mathrm{kV}$.

Energy-dispersive microanalysis was used to obtain maps of chemical elements on transverse sections of undestroyed nodules. Point electron microprobe analysis was used to study the spatial distribution of chemical elements in individual nodules according (Table 1) to 38 energy-dispersive spectra.

The ecological and geochemical assessment of the elemental chemical composition of nodules was carried out using the accumulation-dispersion coefficients (Table 2): KKsoIL,

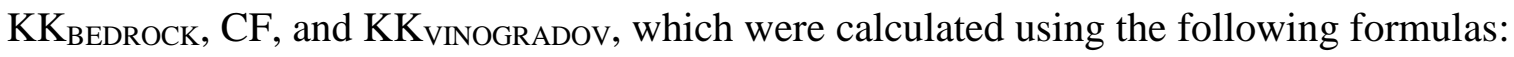

Concentration factor relative to soil composition before nodule extraction $\left(\mathrm{KK}_{\mathrm{SOIL}}\right)$ :

$$
K K_{\text {SOIL }}=\frac{C}{C_{S O I L}}
$$

$\mathrm{C}_{1}$ - concentration of the $\mathrm{i}$-th chemical element in nodules, ppm;

Csoll - concentration of the i-th chemical element in the soil before extraction of nodules, ppm. 
Gorohova S.M., Vasilev A.A. Ecological and geochemical assessment of the content of chemical elements and features of their spatial distribution in Fe nodules of soils in the Middle Cis-Urals

Concentration factor relative to bedrock $\left(\mathrm{KK}_{\mathrm{BEDROCK}}\right)$ :

$$
K K_{\text {BEDROCK }}=\frac{C}{C_{B E D R O C K}}
$$

$\mathrm{C}$ - concentration of the $\mathrm{i}$-th chemical element in the soil component (soil, concretions), ppm;

$\mathrm{C}_{\text {BEDROCK }}$ - concentration of the i-th chemical element in the bedrock, ppm.

The KKSOIL value was estimated as follows: if $\mathrm{KK}_{\mathrm{SOIL}} \geq 1$, then the nodules are enriched in the $\mathrm{i}$-th chemical element. When $\mathrm{KK}_{\text {SOIL }}<1$, then the nodules are depleted in the $\mathrm{i}$-th chemical element.

The concentration coefficient relative to the clarke of the lithosphere according to A.P. Vinogradov (KK LITHOSPHERE) [48]:

$$
K K_{\text {LITHOSPHERE }}=\frac{C}{C_{\text {LITHOSPHERE }}}
$$

$\mathrm{C}_{\text {Lithosphere }}$ - clarke of the i-th chemical element of the lithosphere according to A.P. Vinogradov [48], ppm.

Contamination factor (CF) [49]:

$$
C F=\frac{C}{C_{B A C K G R O U N D}}
$$

$\mathrm{C}_{\mathrm{BACKGROUND}}$ - concentration of the i-th chemical element of the background according to I.S. Kopylov [23], ppm .

Concentration coefficient relative to clarke of world soils according to A.P. Vinogradov (KKVINOGRADOV) [50]:

$$
K K_{\text {VINOGRADOV }}=\frac{C}{C_{\text {VINOGRADOV }}}
$$

CVinogradov - clarke of the i-th chemical element of the soils of the world according to A.P. Vinogradov [50], ppm.

When using $\mathrm{KK}_{\mathrm{LithOSPHERE}}, \mathrm{CF}$, and KKVINOGRADOv soil pollution was classified as follows: $\mathrm{x}<1$ "low contamination", $1 \leq \mathrm{x}<3$ "moderate contamination", $3 \leq \mathrm{x}<6$ "considerable contamination", $\mathrm{x}>6$ "very high contamination" [49].

Statistical processing of the research results was carried out in the MS Office 2010 software package according to E. A. Dmitriev [51]. 
Gorohova S.M., Vasilev A.A. Ecological and geochemical assessment of the content of chemical elements and features of their spatial distribution in Fe nodules of soils in the Middle Cis-Urals

\section{Results and discussion}

The physicochemical properties of the Haplic Fluvisols Oxyaquic were as follows: the organic carbon content is medium (2.5\%), sum of exchange bases is very high $(49.6 \mathrm{cmolc} / \mathrm{kg})$, and exchangeable soil acidity is neutral $(\mathrm{pH}=7.1)$. The Luvic Stagnosols Dystric had a low organic carbon content (1.6\%), a low amount of sum of exchange bases $(9.7 \mathrm{cmolc} / \mathrm{kg})$, and a strongly acid reaction of the exchangeable soil acidity $(\mathrm{pH}=4.3)$. The Umbric Albeluvisols Abruptic is characterized by a low content of organic carbon content (1.3\%), an average amount of sum of exchange bases $(11.0 \mathrm{cmolc} / \mathrm{kg})$ and a strongly acid reaction of the exchangeable soil acidity $(\mathrm{pH}=4.5)$.

The Haplic Fluvisols Oxyaquic contained concretion tubes or rorensteins. These nodules had a cylindrical shape with a through channel along the axis, the size was from 5 to $30 \mathrm{~mm}$. The color of rorensteins is brown-ocher and rusty-brown, due to the biochemical and microbiological precipitation of iron compounds from the soil solution on the surface of dead root bodies. The cross section of rorensteins has a concentric structure, which reflects the periodicity of development and the relatively slow rate of formation of nodules under dynamic redox conditions in floodplain soils.

Spherical concretions or ortsteins were formed in the Luvic Stagnosols Dystric and Umbric Albeluvisols Abruptic. The color of the ortsteins is brown-ocher and rusty-brown like that of rorensteins. The size of nodules is from 0.25 to $2.0 \mathrm{~mm}$. In the Luvic Stagnosols Dystric, the AY horizon contained nodules $7.4 \%$ of the horizon mass, and in the Eg horizon almost two times less $-4.6 \%$ of the horizon mass. The content of concretions in the AY horizon of the Umbric Albeluvisols Abruptic was $2.7 \%$ of the horizon mass.

The concentrations of the $H M$ and Fe in soils and concretions differ (Table 1).

The gray-humus and podzolic horizons of the Luvic Stagnosols Dystric with signs of gleying (pit 1-S) are depleted in $\mathrm{Cu}, \mathrm{Ni}, \mathrm{Zn}$, and $\mathrm{Fe}$. The content of Co is estimated as increased relative to the clarke for the soils of the world. The AY horizon is enriched in $\mathrm{Mn}$ and $\mathrm{Pb}$ relative to the parent rock.

The gray-humus horizon of the Umbric Albeluvisols Abruptic (pit 1-Ch-z) is enriched in Co and $\mathrm{Zn}$, in relation to all used geochemical constants. The horizon is characterized by an increased content of Ni relative to the regional background, as well as Mn relative to the parent rock and clarke for soils of the world. Weak contamination of the Umbric Albeluvisols Abruptic 
Gorohova S.M., Vasilev A.A. Ecological and geochemical assessment of the content of chemical elements and features of their spatial distribution in Fe nodules of soils in the Middle Cis-Urals

Электронный научно-производственньй жсурнал «ӒгроЭкоИнфо»

with $\mathrm{Co}$ and $\mathrm{Zn}$ is probably due to the activity of machine-building enterprises and thermal power plants located on the southern outskirts of Perm.

Table 1. Content of chemical elements in soils and nodules, values of geochemical constants, $\operatorname{ppm}(\mathrm{n}=3)$

\begin{tabular}{|c|c|c|c|c|c|c|c|c|}
\hline $\begin{array}{c}\text { Horizon, } \\
\text { depth, cm }\end{array}$ & Sample & $\mathrm{Fe}$ & $\mathrm{Mn}$ & $\mathrm{Cu}$ & $\mathrm{Ni}$ & $\mathrm{Co}$ & $\mathrm{Zn}$ & $\mathrm{Pb}$ \\
\hline \multicolumn{8}{|c|}{ Pit 1-S. Luvic Stagnosols Dystric } \\
\hline \multirow{2}{*}{ AY, 5-15 } & soil & 9685.00 & 4322.17 & 20.13 & 21.38 & 11.32 & 42.14 & 18.24 \\
\cline { 2 - 10 } & concretions & 32251.96 & 7808.53 & 22.12 & 23.34 & 122.28 & 58.88 & 56.26 \\
\hline \multirow{2}{*}{ Eg, 15-30 } & soil & 9898.00 & 835.81 & 16.19 & 19.30 & 13.07 & 34.86 & 8.72 \\
\cline { 2 - 10 } & concretions & 38738.32 & 10249.00 & 75.93 & 40.02 & 244.33 & 42.54 & 55.03 \\
\hline BT, 40-70 & soil & 15557.00 & 505.45 & 30.56 & 41.16 & 11.50 & 36.32 & 12.11 \\
\hline \multicolumn{7}{|c|}{ Pit 1-Ch-z. Umbric Albeluvisols Abruptic } \\
\hline \multirow{2}{*}{ AY, 2-29 } & soil & 11850.82 & 925.58 & 28.35 & 39.89 & 21.29 & 99.35 & 0.00 \\
\cline { 2 - 10 } & concretions & 48034.08 & 2686.60 & 74.91 & 94.62 & 376.89 & 476.18 & 0.00 \\
\hline C, 100-110 & soil & 25405.72 & 364.29 & 53.50 & 59.45 & 15.22 & 36.52 & 0.00 \\
\hline Clarke of the lithosphere & 46500 & 1000 & 47 & 58 & 18 & 83 & 16 \\
\hline \multicolumn{2}{|c|}{ Clarke of world soils } & 38000 & 850 & 20 & 40 & 8 & 50 & 10 \\
\hline \multicolumn{2}{|c|}{ Background } & - & 900 & 50 & 35 & 17 & 70 & 22 \\
\hline
\end{tabular}

Note: "-" means no data

Table 2. Accumulation-dispersion coefficients of chemical elements (KK) and contamination factor (CF) for soils, according to atomic absorption spectrometry data

\begin{tabular}{|c|c|c|c|c|c|c|c|c|}
\hline Horizon, depth, cm & Indicator & $\mathrm{Fe}$ & $\mathrm{Mn}$ & $\mathrm{Cu}$ & $\mathrm{Ni}$ & $\mathrm{Co}$ & $\mathrm{Zn}$ & $\mathrm{Pb}$ \\
\hline \multicolumn{9}{|c|}{ Pit 1-S. Luvic Stagnosols Dystric } \\
\hline \multirow{4}{*}{ AY, 5-15 } & $\mathrm{KK}_{\mathrm{BEDROCK}}$ & 0,5 & 1,7 & 0,5 & 0,5 & 0,9 & 0,9 & 1,5 \\
\hline & KK $_{\text {LITHOSPHERE }}$ & 0,2 & 0,8 & 0,4 & 0,4 & 0,6 & 0,5 & 1,1 \\
\hline & $\mathrm{CF}$ & - & 0,9 & 0,4 & 0,6 & 0,7 & 0,6 & 0,8 \\
\hline & KK VINOGRADOV $_{\text {VII }}$ & 0,3 & 1,0 & 0,9 & 0,5 & 1,4 & 0,8 & 1,8 \\
\hline \multirow{4}{*}{$\mathrm{Eg}, 15-30$} & $\mathrm{KK}_{\text {BEDROCK }}$ & 0,5 & 1,0 & 0,4 & 0,5 & 1,0 & 0,6 & 0,7 \\
\hline & KK $_{\text {LITHOSPHERE }}$ & 0,2 & 0,5 & 0,3 & 0,3 & 0,7 & 0,3 & 0,5 \\
\hline & $\mathrm{CF}$ & - & 0,5 & 0,3 & 0,6 & 0,8 & 0,4 & 0,4 \\
\hline & KKVINOGRADOV & 0,3 & 0,6 & 0,8 & 0,5 & 1,6 & 0,6 & 0,9 \\
\hline \multicolumn{9}{|c|}{ Pit 1-Ch-z. Umbric Albeluvisols Abruptic } \\
\hline \multirow{4}{*}{ AY, 2-29 } & $\mathrm{KK}_{\mathrm{BEDROCK}}$ & 0,5 & 2,5 & 0,5 & 0,7 & 1,4 & 2,7 & $*$ \\
\hline & KK $_{\text {LITHOSPHERE }}$ & 0,3 & 0,9 & 0,6 & 0,7 & 1,2 & 1,2 & $*$ \\
\hline & $\mathrm{CF}$ & - & 1,0 & 0,6 & 1,1 & 1,3 & 1,4 & $*$ \\
\hline & KK VINOGRADOV $_{\text {VIN }}$ & 0,3 & 1,1 & 1,4 & 1,0 & 2,7 & 2,0 & $*$ \\
\hline
\end{tabular}

Note: "*" is not valid, because $\mathrm{Pb}$ content $=0 \mathrm{ppm}$

Concretions of the Umbric Albeluvisols Abruptic and Luvic Stagnosols Dystric accumulate $\mathrm{Cu}, \mathrm{Ni}, \mathrm{Co}, \mathrm{Zn}, \mathrm{Mn}$, and $\mathrm{Pb}$ (Fig. 2). 
Gorohova S.M., Vasilev A.A. Ecological and geochemical assessment of the content of chemical elements and features of their spatial distribution in Fe nodules of soils in the Middle Cis-Urals

Электронный научно-производственный жсурнал «АгроЭкоИнфо»

The coefficients of accumulation-dispersion of heavy metals in the concretions of grayhumus horizons of soils form the following geochemical series.

1. relative to the soil before nodule extraction

- $\quad$ Luvic Stagnosols Dystric: Co 10,8 $>\mathrm{Fe}$ 3,3 $>\mathrm{Pb} 3,1>\mathrm{Mn} 1,8>\mathrm{Zn}$ 1,4 $>\mathrm{Cu}$ 1,1 > Ni 1,1;

- $\quad$ Umbric Albeluvisols Abruptic: Co 17,7 > Zn 4,8 > Fe 4,1 > Mn 2,9 >Cu 2,6 > Ni 2,4.

2. relative to the bedrock

- $\quad$ Luvic Stagnosols Dystric: Mn 15,4 >Co 10,6 > Pb 4,6 > Fe 2,1 > Zn 1,6 >Cu 0,7 >Ni 0,6

- $\quad$ Umbric Albeluvisols Abruptic: Co 24,8 $>\mathrm{Zn}$ 13,0 $>\mathrm{Mn}$ 7,4 $>\mathrm{Fe} 1,9>\mathrm{Ni} 1,6>\mathrm{Cu} 1,4$.
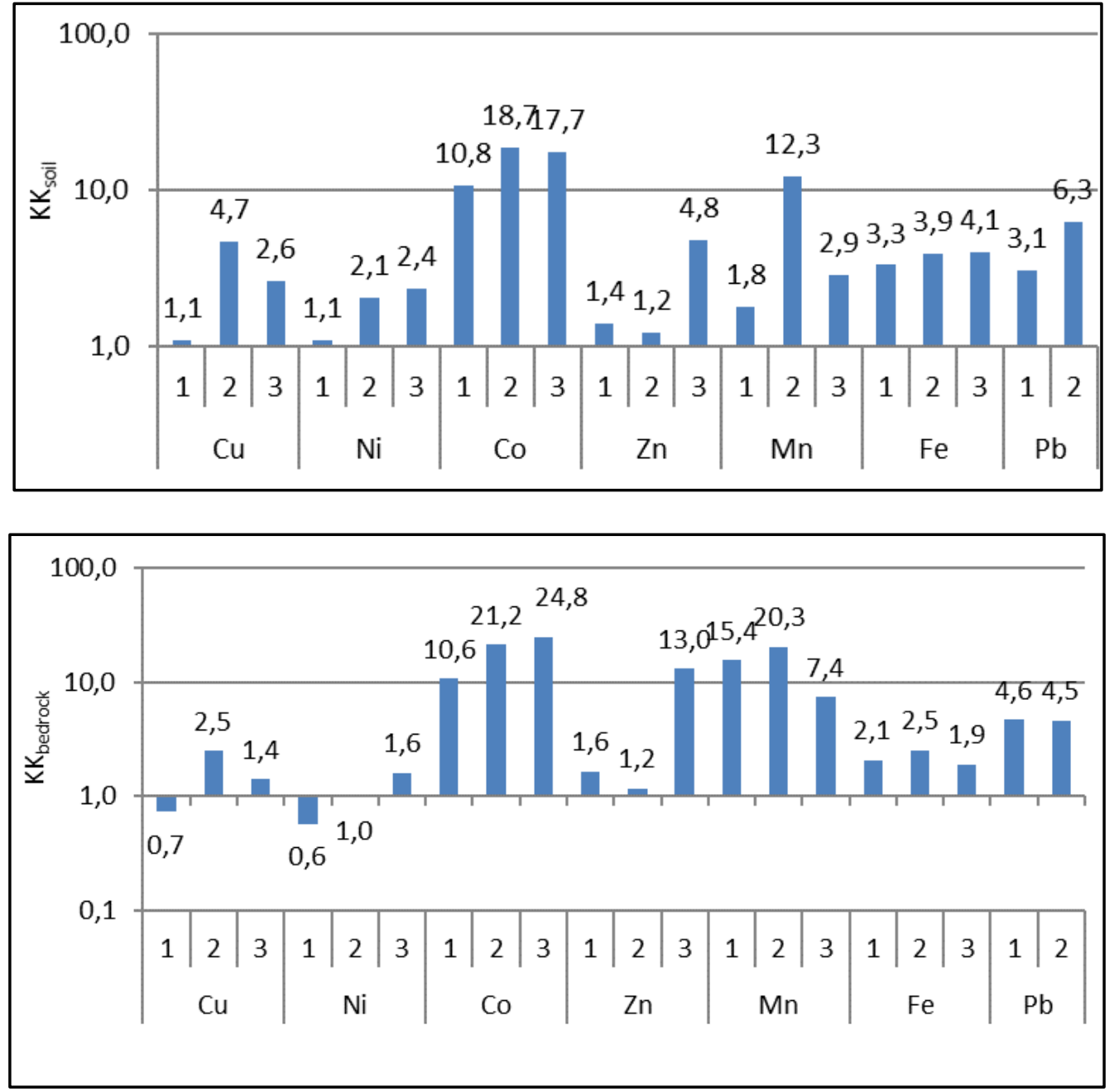
Gorohova S.M., Vasilev A.A. Ecological and geochemical assessment of the content of chemical elements and features of their spatial distribution in Fe nodules of soils in the Middle Cis-Urals

Электронный научно-производственный жсурнал «ӒгроЭкоИнфо»
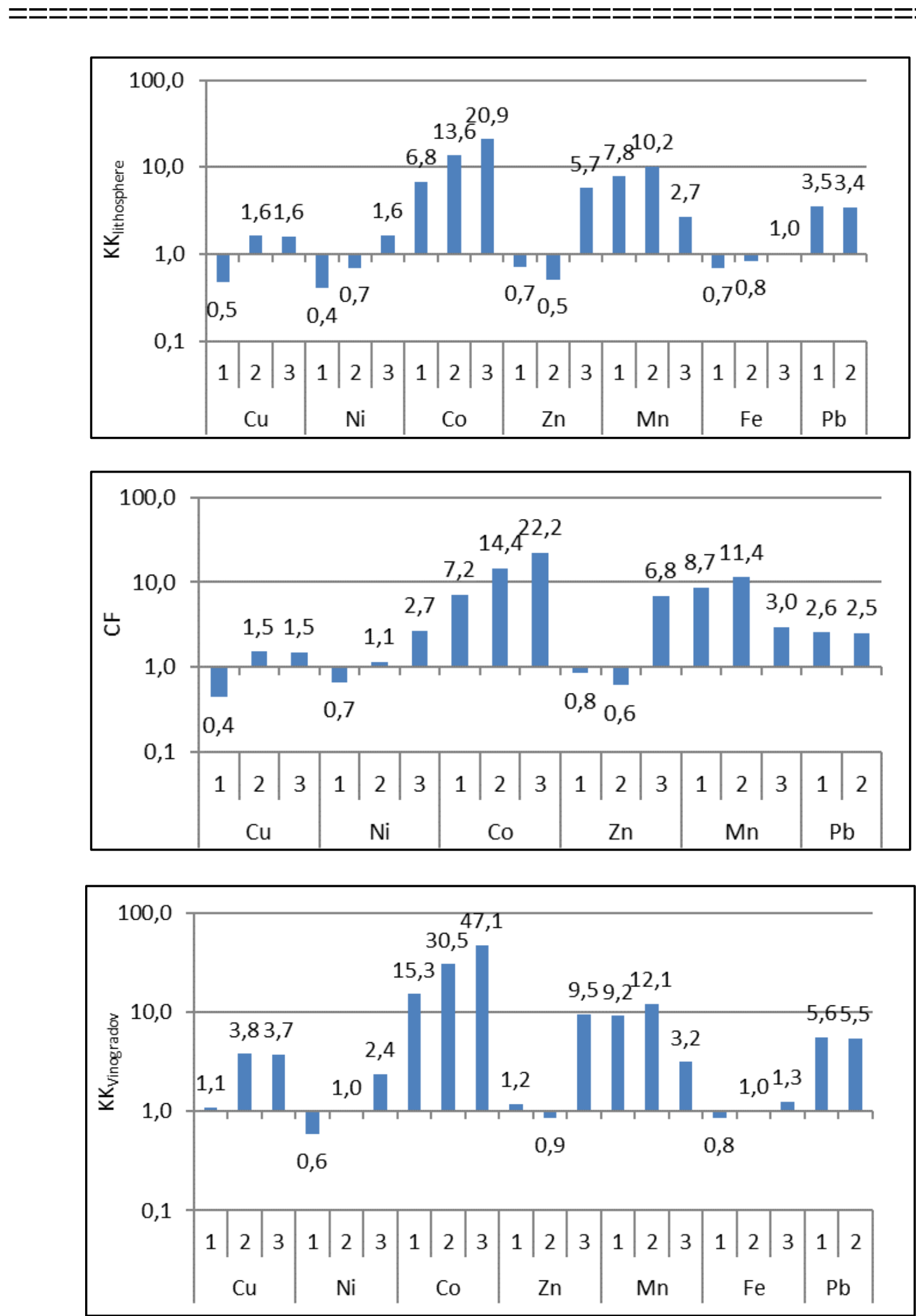

Fig. 2. Accumulation-dispersion coefficients of iron and heavy metals in nodules

Notes: 1 - nodules isolated from sod-shallow podzolic clay superficially peeled soil, section 1-C, horizon AY, 5-15 cm; 2 - nodules isolated from sod-shallow podzolic clay superficially peeled soil, section 1-C, horizon AY, 15-30 cm; 3 - nodules isolated from sod-deep podzolic heavy loamy soil, section 1-H- z, horizon AY, $2-29 \mathrm{~cm}$. 
Gorohova S.M., Vasilev A.A. Ecological and geochemical assessment of the content of chemical elements and features of their spatial distribution in Fe nodules of soils in the Middle Cis-Urals

Figures $3 \mathrm{~A}-3 \mathrm{C}$ show electron microprobe images in reflected electrons of the surface of thin sections of transverse sections of nodules. The light gray color on cross sections of nodules is due to the presence of iron, manganese, titanium, and heavy metal atoms with a mass of about 50 units or more. Dark gray color on micrographs - zones in which compounds of chemical elements with low atomic mass predominate - carbon, nitrogen, aluminum, silicon, phosphorus, potassium, etc.

The rorenstein formed in the gley horizon of Haplic Fluvisols Oxyaquic (pit 1-N) is distinguished by the preservation of the morphological structure of the root fragment, around which a rhizoconcretion formed due to its replacement and overgrowth. In the center of the inner part of the nodule, there is a well-defined cavity, the inner axial canal of the rorenstein. The inner part of the rorenstein, from the axial channel to the outer shell, is clearly divided by color in the reflected electrons into three layers: the first one has the darkest ring in the center; the second is the largest ring, which has a predominantly light gray color; the third is the thin outer dark ring or sheath of the rhizoconcretion (Fig. $3 \mathrm{~A}$ ).

A spherical nodule or nodule separated from the gray-humus horizon of the Luvic Stagnosols Dystric has a concentric structure. Three components of the concretion are distinguished: the core, the outer shell and the inner dividing ring. Accumulations of metal compounds with high atomic mass are clearly fixed as a light ring on the surface of the nucleus (Fig. 3 B).

On the transverse section of the nodules from the gray-humus horizon of the Umbric Albeluvisols Abruptic, two parts are distinguished. The first part is a gray core, the second part is a dark gray shell of the core. In the micrograph in the reflected electrons, the gray color of the nucleus and its shell is due to the predominance of atoms of chemical elements with a mass of less than 50 units (Fig. 3 C).

The creation of color ESM/EDS maps of the distribution of chemical elements on cross sections of ferruginous nodules made it possible to clarify the spatial heterogeneity of the elemental chemical composition of neoformations (Fig. 3 D - F).

The rorenstein body is characterized by a well-defined concentric distribution of some chemical elements (Fig. 3 D). Phosphorus and manganese are accumulated in the inner ring of the rhizoconcretion encircling the axial canal of the glandular tubule. At the morphological level, this area consists of cells of the vascular bundles of the plant root. The largest area in the 
Gorohova S.M., Vasilev A.A. Ecological and geochemical assessment of the content of chemical elements and features of their spatial distribution in Fe nodules of soils in the Middle Cis-Urals

Электронный научно-производственный жсурнал «АгроЭкоИнфо»

transverse section of the rhizoconcretion is occupied by an aluminosilicate layer impregnated, possibly, with iron hydroxides. The second manganese-iron layer is the outer shell of the rorenstein. In addition, accumulations of iron compounds of a focal nature were revealed, due to the vital activity of colonies of iron-reducing microorganisms (Fig. 3 D) [29].

The spatial distribution of chemical elements within the body of the ortstein isolated from the gray-humus horizon of the Luvic Stagnosols Dystric is heterogeneous (Fig. 3E). Iron is concentrated in the central part of the ortstein. The ortstein core is the center of concretion formation. Colonies of iron-reducing bacteria initially formed on the surface of a particle of magnetite, maghemite, hematite, or another iron mineral. The body of the ortstein gradually "expanded" due to the ferruginization of the aluminosilicate clay matrix of the soil surrounding the nodule formation center, the growth occurs due to the "sticking" of the soil mass from the enclosing matrix. Manganese (1.3\%) forms a well-defined annular framework on the surface of the glandular core within the nodule (Fig. 3 E).

On the distribution map of chemical elements, iron is confined to the periphery of the cross section of the ortstein of Umbric Albeluvisols Abruptic (Fig. 3 F).

The studied nodules and rorensteins are characterized by a general regularity in the spatial distribution of chemical elements: from the center of the concretion to the periphery, the content of iron increases and the content of manganese decreases (Fig. $3 \mathrm{G}-\mathrm{I}$ ).

The content of iron and manganese in nodules varied: $\mathrm{Fe} 1.67-19.22 \%, \mathrm{Mn} 0.25-3.71 \%$ (Table 3). The concentration of other macroelements in the composition of the aluminosilicate part varied in a wide range: Si 6.57-25.58\%, Al 3.97-22.07\%, Mg 0.39-1.68\%, K 0.38-1.13 \%, $\mathrm{Ca} 0.09-0.65 \%$, Na 0.65-1.14\%. Abnormally high content of nitrogen was revealed - $29700 \mathrm{ppm}$ and phosphorus - $900 \mathrm{ppm}$. This confirms the biogenic nature of nodule formation, i.e., the participation of microbial colonies in the formation of ferruginous nodules [52]. The content of heavy metals and titanium was as follows: $\mathrm{Co}-$ up to $700 \mathrm{ppm}, \mathrm{Cr}-$ up to $700 \mathrm{ppm}, \mathrm{Ti}-$ from 1600 to $39100 \mathrm{ppm}$.

The local accumulation of $\mathrm{Fe}, \mathrm{Mn}, \mathrm{Cr}$, Ti, and $\mathrm{N}$ was revealed in nodules relative to the regional background and clarke of world soils according to A.P. Vinogradov. The content of magnesium and sodium in some local zones of nodules exceeds the clarke of the soils of the world (Table 4). 
Gorohova S.M., Vasilev A.A. Ecological and geochemical assessment of the content of chemical elements and features of their spatial distribution in Fe nodules of soils in the Middle Cis-Urals

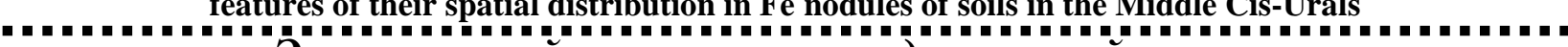
Электронный научно-производственный жсурнал «ӒгроЭкоИнфо»

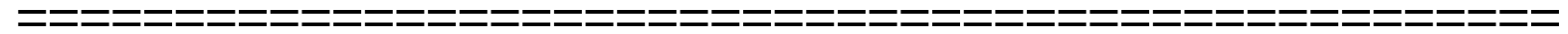

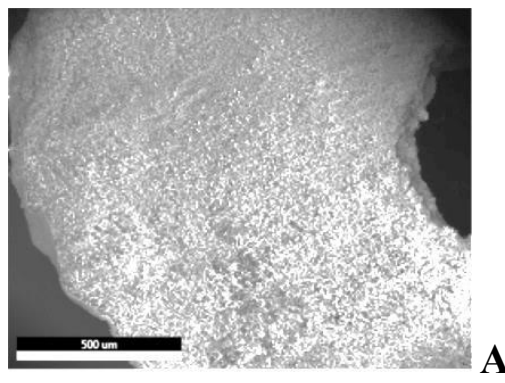
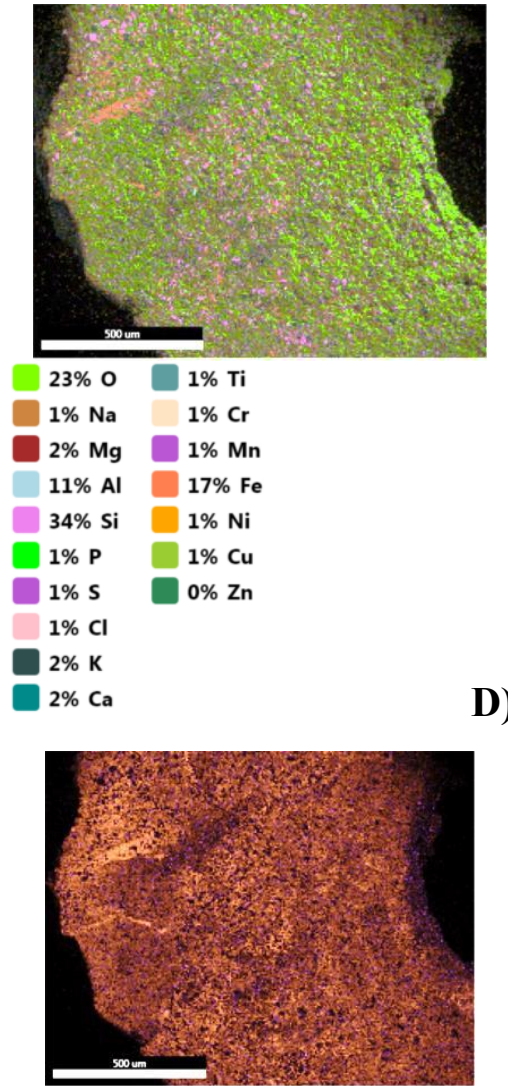

$5 \% \mathrm{Mn}$

$95 \% \mathrm{Fe}$

Haplic Fluvisols Oxyaquic, pit 1-N, horizon $\mathrm{G}, 64-72 \mathrm{~cm}$

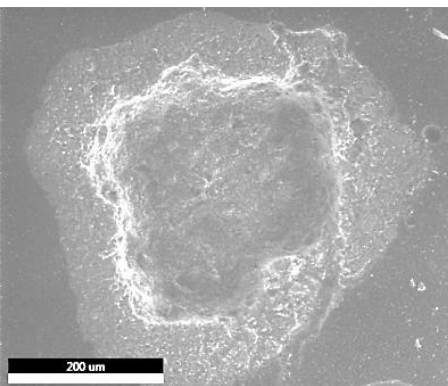

B)
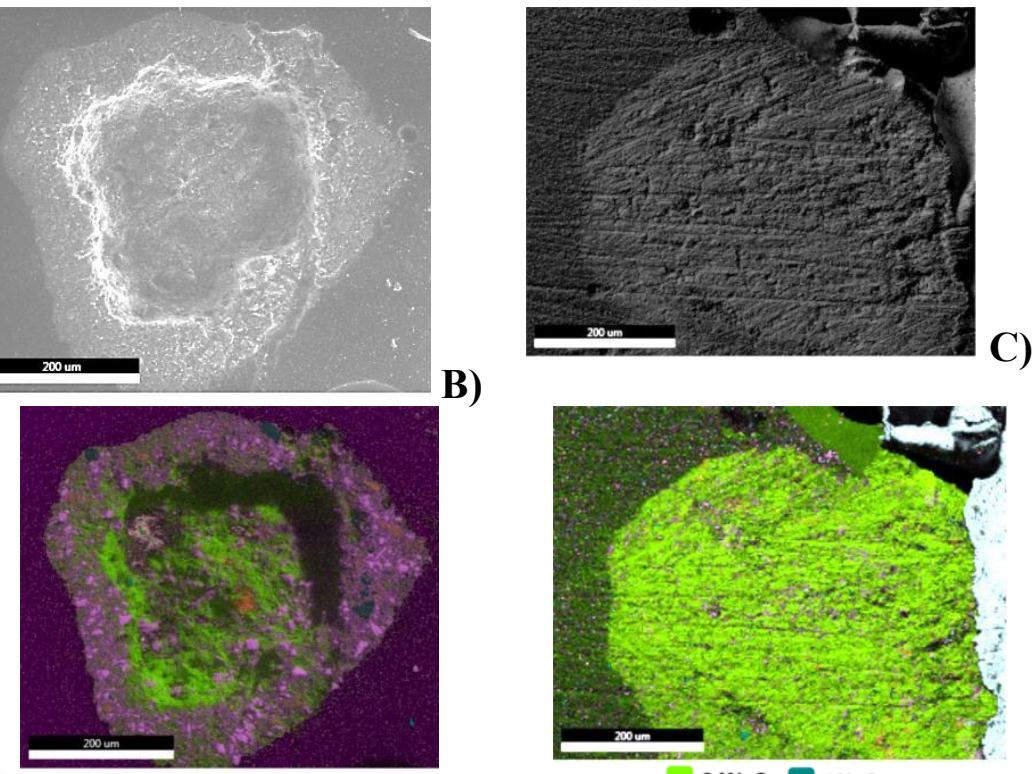

$26 \% \mathrm{C}-2 \% \mathrm{~K}$

$1 \% \mathrm{~N} \square \mathrm{Ca}$

$17 \% \circ 1 \% \mathrm{~T}$

$1 \% \mathrm{Na} 1 \% \mathrm{Mn}$

$2 \% \mathrm{Mg} \quad 3 \% \mathrm{Fe}$

$19 \%$ Al

$24 \% \mathrm{Si}$

$1 \% \mathrm{P}$

$1 \% \mathrm{~S}$

D)

$1 \% \mathrm{Cl}$

E)

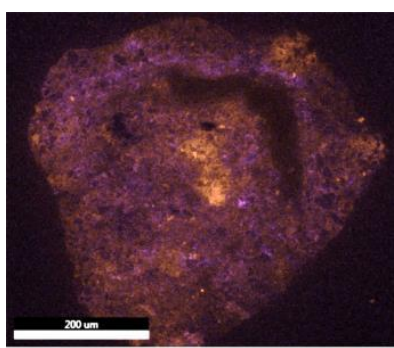

$28 \% \mathrm{Mn}$

$72 \% \mathrm{Fe}$

Luvic Stagnosols Dystric, pit 1-S, horizon AY, 5-15 cm

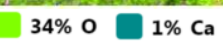

$4 \% \mathrm{Fe} 2 \% \mathrm{Ti}$

$3 \% \mathrm{Na} \quad 1 \% \mathrm{Cr}$

$0 \% \mathrm{Mg} 1 \% \mathrm{Mn}$

$21 \%$ Al

$27 \% \mathrm{Si}$

$1 \% \mathrm{P}$

$1 \% \mathrm{~S}$

$1 \% \mathrm{Cl}$

$1 \% \mathrm{~K}$

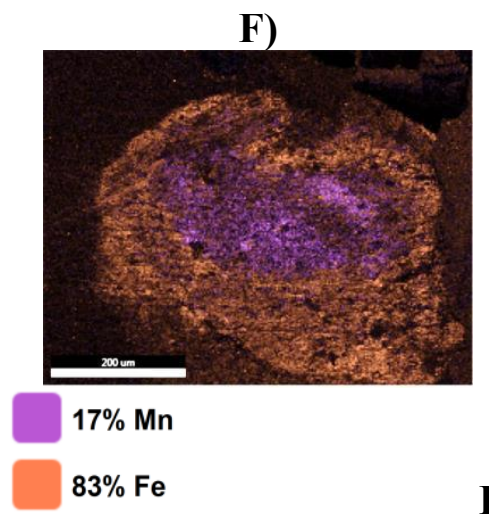

Umbric Albeluvisols Abruptic,

pit 1-Ch-z, horizon AY, 2-

$29 \mathrm{~cm}$

Fig. 3. Results of SEM/EDS analysis of polished sections of nodules in soils of the Middle Cis-

Urals: A-C - microimages in reflected electrons; D-F - maps of the spatial distribution of chemical elements; G-I - maps of the spatial distribution of iron and manganese 


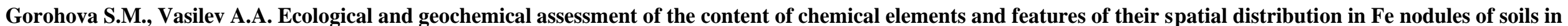
the Middle Cis-Urals

\section{Электронный научно-производственный жнурнал}

«АгроЭкоИнфо»

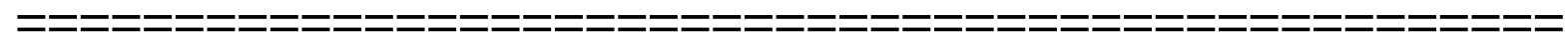

Table 3. Elemental chemical composition on sections of undestroyed nodules, according to energy-dispersive analysis data at individual points

\begin{tabular}{|c|c|c|c|c|c|c|c|c|c|c|c|c|c|c|c|c|c|}
\hline \multirow{2}{*}{ Object } & \multirow{2}{*}{$\begin{array}{l}\text { Horizon, } \\
\text { depth, cm } \\
\end{array}$} & \multirow{2}{*}{$\begin{array}{l}\text { Number of } \\
\text { points, pcs. }\end{array}$} & $\mathrm{O}$ & $\mathrm{C}$ & $\mathrm{N}$ & $\mathrm{Si}$ & $\mathrm{Al}$ & $\mathrm{Fe}$ & $\mathrm{Mn}$ & $\mathrm{Ca}$ & $\mathrm{Mg}$ & $\mathrm{K}$ & $\mathrm{Na}$ & $\mathrm{P}$ & $\mathrm{Ti}$ & $\mathrm{Co}$ & $\mathrm{Cr}$ \\
\hline & & & \multicolumn{15}{|c|}{$\%$} \\
\hline $\begin{array}{c}\text { Pit 1-N. Haplic Fluvisols } \\
\text { Oxyaquic }\end{array}$ & $\mathrm{G}, 64-72$ & 16 & 46,79 & 12,89 & $*$ & 14,50 & 3,97 & 19,22 & $*$ & 0,09 & 0,49 & 0,82 & 0,84 & 0,09 & 0,24 & 0,07 & $*$ \\
\hline $\begin{array}{c}\text { Pit 1-S. Luvic Stagnosols } \\
\text { Dystric }\end{array}$ & AY, 5-15 & 12 & 32,95 & 48,74 & 2,97 & 6,57 & 5,05 & 1,67 & 0,25 & 0,20 & 0,39 & 0,38 & 0,65 & 0,00 & 0,16 & $*$ & $*$ \\
\hline $\begin{array}{c}\text { Pit 1-Ch-z. Umbric } \\
\text { Albeluvisols Abruptic }\end{array}$ & AY, 2-29 & 10 & 35,35 & - & $*$ & 25,58 & 22,07 & 4,66 & 3,71 & 0,65 & 1,68 & 1,13 & 1,14 & 0,04 & 3,91 & $*$ & 0,07 \\
\hline
\end{tabular}

Note: "-" - the indicator was not determined; "*" - content below the detection limit.

Table 4. Concentration-scattering coefficients of chemical elements on sections of undestroyed nodules, according to energy-dispersive analysis data at individual points

\begin{tabular}{|c|c|c|c|c|c|c|c|c|c|c|c|c|c|c|c|c|}
\hline Object & $\begin{array}{l}\text { Horizon, } \\
\text { depth, cm }\end{array}$ & $\begin{array}{l}\text { Number of } \\
\text { points, pcs. }\end{array}$ & $\mathrm{O}$ & $\mathrm{N}$ & $\mathrm{Si}$ & $\mathrm{Al}$ & $\mathrm{Fe}$ & $\mathrm{Mn}$ & $\mathrm{Ca}$ & $\mathrm{Mg}$ & $\mathrm{K}$ & $\mathrm{Na}$ & $\mathrm{P}$ & $\mathrm{Ti}$ & $\mathrm{Co}$ & $\mathrm{Cr}$ \\
\hline \multicolumn{17}{|c|}{ KK $_{\text {BACKGROUND }}$} \\
\hline $\begin{array}{c}\text { Pit 1-N. Haplic } \\
\text { Fluvisols Oxyaquic }\end{array}$ & $\mathrm{G}, 64-72$ & 16 & 1,14 & - & 0,56 & 0,57 & 4,75 & - & 0,03 & 0,30 & 0,38 & 0,39 & 1,13 & 0,60 & 43,73 & - \\
\hline $\begin{array}{c}\text { Pit 1-S. Luvic } \\
\text { Stagnosols Dystric }\end{array}$ & AY, 5-15 & 12 & 1,37 & 3049,47 & 0,43 & 1,22 & 0,70 & 4,88 & 0,13 & 0,41 & 0,30 & 0,51 & 0,00 & 0,69 & - & - \\
\hline $\begin{array}{l}\text { Pit 1-Ch-z. Umbric } \\
\text { Albeluvisols Abruptic }\end{array}$ & AY, 2-29 & 10 & 0,75 & - & 0,87 & 2,74 & 1,00 & 37,10 & 0,22 & 0,90 & 0,45 & 0,46 & 0,43 & 8,69 & - & 8,43 \\
\hline \multicolumn{17}{|c|}{ KKVINOGRADOV } \\
\hline $\begin{array}{c}\text { Pit 1-N. Haplic } \\
\text { Fluvisols Oxyaquic }\end{array}$ & $\mathrm{G}, 64-72$ & 16 & - & - & 0,50 & 0,64 & 5,81 & - & 0,07 & 0,90 & 0,69 & 1,53 & 1,31 & 0,59 & 98,39 & - \\
\hline $\begin{array}{c}\text { Pit 1-S. Luvic } \\
\text { Stagnosols Dystric }\end{array}$ & AY, 5-15 & 12 & - & 57,94 & 0,39 & 1,38 & 0,86 & 5,74 & 0,28 & 1,21 & 0,55 & 2,01 & 0,00 & 0,68 & - & - \\
\hline $\begin{array}{l}\text { Pit 1-Ch-z. Umbric } \\
\text { Albeluvisols Abruptic }\end{array}$ & AY, 2-29 & 10 & - & - & 0,78 & 3,10 & 1,23 & 43,65 & 0,47 & 2,67 & 0,83 & 1,81 & 0,50 & 8,50 & - & 3,50 \\
\hline
\end{tabular}

Note: "-" - the content is below the detection limit 
Gorohova S.M., Vasilev A.A. Ecological and geochemical assessment of the content of chemical elements and features of their spatial distribution in Fe nodules of soils in the Middle Cis-Urals

\section{Conclusions}

Fe nodules are geochemical barriers and accumulate $\mathrm{Cu}, \mathrm{Ni}, \mathrm{Co}, \mathrm{Zn}, \mathrm{Mn}$, and $\mathrm{Pb}$ in the Haplic Fluvisols Oxyaquic, the Luvic Stagnosols Dystric, and the Umbric Albeluvisols Abruptic. SEM/EDS mapping revealed a concentric ring structure of nodules with alternating phases rich in $\mathrm{Fe}$ and $\mathrm{Mn}$. The core of the nodules is enriched in manganese. The ring-centric structure of nodules reflects contrasting redox conditions of soil formation and precipitation of metals in soils of the Middle Cis-Urals under conditions of temporary excess moisture.

The reported study was funded by RFBR, project number 19-34-90070.

\section{Bibliography}

1. Vasiliev A.A. Hydrological regime, properties and diagnostics of soddy-podzolic surface gleyed soils on cover deposits of the Cis-Urals: thesis ... cand. agr. sciences: 03.00.27. Moscow. - 1994. - 216 p.

2. Gilev V.Yu. Oxidogenesis and reductogenesis in soils on the eluvium and deluvium of Permian clays of the Middle Cis-Urals: thesis ... cand. agr. sciences: 06.01.03. Moscow. - 2007. $-141 \mathrm{p}$.

3. Sataev E.F. Regimes and oxidogenesis of soils on ancient alluvial deposits of the Middle Kama lowland plain: thesis ... cand. agr. sciences: 06.01.03. Moscow. - 2005. - 140 p.

4. Vasiliev A.A., Romanova A.V. Iron and heavy metals in alluvial soils of the Middle Cis-Urals. - Perm: IPC Prokrost, 2014. - 231 p.

5. Drosdoff M., Nikiforoff C.C. Iron-manganese concretions in Dayton soils // Soil Science. LWW. - 1940. - Vol. 49. - № 5. - P. 333-346.

6. Zaidelman F.R., Nikiforova A.S. Genesis and diagnostic value of new soil formations in the forest and forest-steppe zones. - Moscow: Publishing House of Moscow State University, 2001. $-216 \mathrm{p}$.

7. Gasparatos D., Massas I., Godelitsas A. Fe-Mn concretions and nodules formation in redoximorphic soils and their role on soil phosphorus dynamics: Current knowledge and gaps // Catena. Elsevier. - 2019. - Vol. 182. - P. 104106.

8. Ettler V. [et al.] Characterization of Fe-Mn concentric nodules from Luvisol irrigated by mine water in a semi-arid agricultural area // Geoderma. Elsevier, - 2017. Vol. 299. - P. 3242.

9. Golov V.I., Timofeeva Ya.O. Ecological functions of soils and their realisation on the example of ferrimanganese concretions // Vestnik KrasGAU. - 2009. - № 5. - P. 16-19.

10. Timofeeva Y.O., Golov V.I. Sorption of heavy metals by iron-manganic nodules in 
Gorohova S.M., Vasilev A.A. Ecological and geochemical assessment of the content of chemical elements and features of their spatial distribution in Fe nodules of soils in the Middle Cis-Urals

Электронный научно-производственный жсурнал «АгроЭкоИнфо»

soils of Primorskii region // Eurasian Soil Sc. - 2007. - № 12. - P. 1463-1471.

11. Vodyanitsky Yu.N. [et al.] Geochemistry of magnetite and maghemite in soils in european Russia // Geochemistry. - 2009. - № 3. - P. 314-327.

12. Vodyanitsky Yu.N. Iron compounds and their role in soil protection. - Moscow: GNU Soil Institute. V.V. Dokuchaev of the Russian Agricultural Academy, 2010. - 156 p.

13. Romanova A.V. Oxidogenesis of iron and manganese and heavy metals in alluvial soils of the southern taiga of the Middle Cis-Urals: thesis ... cand. biol. sciences: 03.02.13. Ufa. - 2012. - 211 p.

14. Antsiferova O.A. Ferromanganese nodules in the soils of the western part of the Kaliningrad region // Bulletin of the Baltic Federal University. I. Kant. Series: Natural and medical sciences. - 2014. - № 1. - P. 73-78.

15. Yashin I.M., Kashansky A.D. Landscape-geochemical diagnostics and genesis of soils of the European North of Russia. 2nd edition. - Minsk: Publishing house of RGAU-MSHA named after K.A. Timiryazev, 2015. - 202 p.

16. Vasiliev A.A., Romanova A.V., Gilev V.Yu. Colour and soil hydromorphism in the Permskii krai // Perm agrarian bulletin. - 2014. - № 1 (5). - P. 28-38.

17. Vasiliev A.A., Vlasov M.N. Redox state and optical properties of urbo-alluvial soils of floodplains of small rivers of the Perm agglomeration // Proceedings of the International Scientific and Practical Conference "INNOVATIONS OF AGRARIAN SCIENCE FOR AIC ENTERPRISES”. - Perm: PGSHA. - 2012. - P. 166-172.

18. Vodyanitsky Yu.N., Vasiliev A.A., Vlasov M.N. Chemical composition of ferromanganese neoformations of soils of the Permian agglomeration and pollution of soils of the territory by heavy metals // Collection of scientific papers of the LXVIII All-Russian Scientific and Practical Conference "PERM AGRARIAN VESTNIK". - Perm: PGSHA. - 2008. - P. 6467.

19. Vodyanitsky Yu.N., Vasiliev A.A., Kozheva A.V. Heavy metals in alluvial soils of the Middle Urals // Doklady RAAS. - 2004. - № 5. - P. 23-24.

20. Vasiliev A.A., Romanova A.V. Magnetic susceptibility of alluvial soils of the floodplains of the Verkhnyaya Mulyanka and Obva rivers in the Perm Territory // Proceedings of the All-Russian Correspondence Scientific and Practical Conference "INNOVATIVE SCIENTIFIC SOLUTIONS - THE BASIS FOR MODERNIZATION OF AGRARIAN ECONOMY". - Perm: PGSHA. - 2011. - P. 61-65.

21. Vasiliev A.A., Lobanova E.S. Cluster analysis of the connection between the content of heavy metals and the ferrimagnetic phase in the soils of Perm // Proceedings of the International scientific-practical conference "ACTUAL PROBLEMS OF SCIENCE AND AGRICULTURE IN THE PROCESS OF EUROPEAN INTEGRATION”, dedicated to the 95th anniversary of higher agricultural education in the Urals. - Perm: PGSHA. - 2013. - P. 207-211.

22. Romanova A.V., Vasiliev A.A. Elemental chemical composition of ortsteins and rorensteins of soils in the floodplains of the Kama, Obva and Verkhnyaya Mulyanka rivers in the 
Gorohova S.M., Vasilev A.A. Ecological and geochemical assessment of the content of chemical elements and features of their spatial distribution in Fe nodules of soils in the Middle Cis-Urals

Perm Territory // Proceedings of the All-Russian Scientific and Practical Conference "Youth Science 2014: Technologies, Innovations". - Perm: CPI Prokrost. - 2014. - Vol. 1. - P. 335-337.

23. Kopylov I.S. Geoecology, hydrogeology and engineering geology of the Perm region. - Perm: PSU, - 2021. - 501 p.

24. Eremchenko O.Z., Shestakov I.E., Moskvina N.V. Soils and technogenic surface formations of urbanized territories of the Perm Kama region. - Perm: PSU, 2016. - 252 p.

25. Wang Q., Jiang Z., Sun Z. The formation environment and spatial distribution of ironmanganese nodules in the Quaternary loess developed soils in northern China // Soil Journal. 2019. - Vol. 56. - № 2. - P. 288-297.

26. Jiang Z.-D. [et al.] Fe-Mn concentrations in upland loess soils in mid-continental north America: A step towards dynamic soil survey // CATENA. Elsevier. - 2021. - Vol. 202. P. 105273.

27. Roslikova V.I., Gyninova A.B. Transformation of solid phase of texturedifferentiated soils of Middle Priamurye as a result of drainage meliorations, and diagnostic implication of Mn-Fe concretions in this process // Pacific Geology. - 2012. - Vol. 31. - № 3. P. 93-104.

28. Zaidelman F.R. [et al.] Dark gray soils on two-layered deposits in the north of Tambov Plain: Agroecology, properties, and diagnostics. Eurasian Soil Sc. - 2012. - № 5. - P. 515-515.

29. Lysak L.V. [et al.] Population number, viability, and taxonomic composition of the bacterial nanoforms in iron-manganic concretions // Eurasian Soil Sc. - 2013. - № 6. - P. 707714.

30. Zaidel'man F.R., Nikiforova A.S. Ferromanganese concretionary neoformations: A review // Eurasian Soil Sc. - 2010. - № 3. - P. 270-281.

31. Sun Z.-X. [et al.] Fe-Mn nodules in a southern Indiana loess with a fragipan and their soil forming significance // Geoderma. Elsevier. - 2018. - Vol. 313. - P. 92-111.

32. Sipos P. [et al.] Changes in micro-fabric and re-distribution of $\mathrm{Fe}$ and $\mathrm{Mn}$ with nodule formation in a floodplain soil // Journal of Soils and Sediments. Springer. - 2016. - Vol. 16. - № 8. - P. 2105-2117.

33. Stepantsova L.V., Volokhina V.P., Nikiforova A.S. Concretionary neoformation dark-gray soils in the double-layer sediments of the norththe tambov plain // Bulletin of the Orenburg State University. - 2012. - № 10 (146). - P. 105-111.

34. Trifonova T.A., Shirkin L.A., Selivanova N.V. Ecological and geochemical analysis of landscape pollution. - Vladimir: Vladimir Polygraph, 2007. - 169 p.

35. Szymański W., Skiba M. Distribution, morphology, and chemical composition of FeMn nodules in Albeluvisols of the Carpathian Foothills, Poland // Pedosphere. Elsevier. - 2013. Vol. 23. - № 4. - P. 445-454.

36. Timofeeva Ya.O. Characteristics of iron-manganese nodules from the soils of the Pacific Ocean coast // Collection of materials of the All-Russian Scientific Conference with 
Gorohova S.M., Vasilev A.A. Ecological and geochemical assessment of the content of chemical elements and features of their spatial distribution in Fe nodules of soils in the Middle Cis-Urals

Электронный научно-производственный жсурнал «АгроЭкоИнфо»

international participation "SOILS IN THE BIOSPHERE", dedicated to the 50th anniversary of the Institute of Soil Science and Agrochemistry SB RAS. - Tomsk: Publishing House of Tomsk State University. - 2018. - Vol. 1. - P. 400-403.

37. Zaidelman F.R. [et al.] Neoformations (Nodules and Placic Layers) in Surface-Gleyed Loamy Sandy Soils of the Northern Part of the Tambov Plain // Eurasian Soil Sc. - 2019. - № 5. - P. 544-557.

38. Yu X., Lu S. Micrometer-scale internal structure and element distribution of Fe-Mn nodules in Quaternary red earth of Eastern China // Journal of soils and sediments. Springer. 2016. - Vol. 16. - № 2. - P. 621-633.

39. Ji W. [et al.] Potential ecological risk assessment of heavy metals in the Fe-Mn nodules in the karst area of Guangxi, southwest China // Bulletin of Environmental Contamination and Toxicology. Springer. - 2021. - Vol. 106. - № 1. - P. 51-56.

40. Isaev A.V. [et al.] Ecogeochemisty of alluvial meadow and sod-meadow soils in Bolshaya Kokshaga nature reserve// Scientific works of the Bolshaya Kokshaga State Nature Reserve. - 2020. - № 9. - P. 30-71.

41. Targulyan V.O. [et al.] Soil memory: soil as a memory of biosphere-geosphereanthroposphere interactions. - Moscow: LKI Publishing House, 2008. - 687 p.

42. Babanin V.F. [et al.] Diagnostics of manganese-iron nodules in soddy-podzolic soils at different degrees of gleyzation from their magnetic properties // Eurasian Soil Sc. - 2007. - № 3. - P. 272-281.

43. Timofeeva Ya.O. TThe role of iron-manganese nodules in accumulation of heavy metals in the soils of areas adjacent to motorway // Bulletin of the Irkutsk State University. Series: Biology. Ecology. - 2013. - Vol. 6. - № 3. - P. 94-99.

44. Vodyanitsky Yu.N., Zaidelman F.R. Iron and Manganese Minerals in Nodules of Soddy-Podzolic Soils with Different Degrees of gleyzation on Different Parent Rocks // Bulletin of Moscow State University. Series 17 Soil science. - 2000. - № 3. - P. 3-12.

45. Vasiliev A.A., Vlasov M.N. Assessment of ecological and geochemical state of alluvial soils of floodplains of small rivers of Perm [Electron. resource] // AgroEcoInfo: Electronic scientific and production journal. - 2021. - No. 2. - Access mode: http://agroecoinfo.ru/STATYI/2021/2/st_202.pdf

46. Korotaev N.Ya. Soils of the Perm region. - Perm: Perm book publishing house, 1962. $-276 \mathrm{p}$.

47. Ganzhara N.F., Borisov B.A., Baibekov R.F. Workshop on soil science. - Moscow: LLC "Reart", 2017. - 164 p.

48. Vinogradov A.P. Average content of chemical elements in rocks // Geochemistry. 1962. - № 7. - P. 555-571.

49. Hakanson L. An ecological risk index for aquatic pollution control. A sedimentological approach // Water research. Elsevier. - 1980. - Vol. 14. - № 8. - P. 975-1001.

50. Vinogradov A.P. Geochemistry of rare and trace elements in soils. - Moscow: 
Gorohova S.M., Vasilev A.A. Ecological and geochemical assessment of the content of chemical elements and features of their spatial distribution in Fe nodules of soils in the Middle Cis-Urals

Электронный научно-производственный жсурнал «АгроЭкоИнфо»

Publishing House of the Academy of Sciences of the USSR, 1957. - $239 \mathrm{p}$.

51. Dmitriev E.A. Mathematical statistics in soil science. - Moscow: URSS, 2008. - 326 p.

52. Aristovskaya T.V. Microbiology of soil formation processes. - Leningrad: Nauka, 1980. -187 p.

\section{Цитирование:}

Gorohova S.M., Vasilev A.A. Ecological and geochemical assessment of the content of chemical elements and features of their spatial distribution in Fe nodules of soils in the Middle Cis-Urals [Electron. resource] // AgroEcoInfo: Electronic scientific and production journal. 2022. - No. 1. - Access mode: http://agroecoinfo.ru/STATYI/2022/1/st_114_eng.pdf.

DOI: https://doi.org/10.51419/2021211140. 